\title{
Sobre gorilas e subversivos: memórias de um Brasil em conflito'
}

\author{
Desirée de Lemos Azevedo \\ Doutoranda em Antropologia Social (Universidade Estadual de Campinas) \\ desireelazevedo@gmail.com
}

\begin{abstract}
Resumo Este artigo pretende refletir sobre o imbricamento de questões relativas a nação, política, conflito e exílio nos processos sociais vividos pelo Brasil nos anos 1960 e 70, inseridos nos marcos mais gerais do que se convencionou chamar de período histórico da Guerra Fria. Para tanto partirei de categorias associadas a esses temas convocadas pelas memórias de ex-exilados políticos brasileiros na construção de narrativas sobre os eventos críticos vividos por eles ao longo dos "anos de chumbo".
\end{abstract}

Palavras-chave: memória, política, nação, exílio, Guerra Fria.

\begin{abstract}
Tós não tiVemos exilados nO BRASIL, nós tivemos fugitivos. Pode ser dura a minha palavra, mas eu não acho que tivemos exilados no Brasil, não houve um decreto de exilar ninguém. Depois que fizeram algumas coisas, quiseram ir embora, então nós criamos os banidos; eles é que quiseram ir embora pra aqui, pra lá, pra acolá, pegaram um avião e saíram por aí, não é??
\end{abstract}

Porque juridicamente a ditadura nos bania. Ora! E, sendo banidos, nós estávamos fora do sistema jurídico brasileiro! Coerentemente com isso, se a gente voltasse, ia ter que ser expulso do Brasil. Evidentemente que isso estava fora de lógica, então eles nos disseram claramente, eu me lembro que o avião fez um... O comandante do avião fez uma volta no Rio de Janeiro, e os torturadores diziam: 'Olha pela última vez, porque, se vocês voltarem, vocês vão morrer; se vocês forem presos, vocês vão morrer!' ${ }^{3}$

O primeiro trecho transcrito em epígrafe foi dito por um general, ex-comandante do I Exército durante os anos 1970, em entrevista recente à televisão, quando se manifestou a respeito de seus antigos opositores e outros assuntos relativos ao período da ditadura militar brasileira (1964-1985). Durante toda a entrevista, chama atenção a centralidade empregada pelo general à oposição "nós" X "eles", que pode ser percebida no trecho citado. Através desse "nós", ora ele quer se referir à ditadura, "nós criamos os banidos", ora à sociedade brasileira de conjunto, "nós não tivemos exilados no Brasil, nós tivemos fugitivos", em oposição aos exilados, "eles" que "quiseram ir embora". Curiosamente, a mesma oposição pode ser vista no segundo excerto, este pronunciado por um ex-opositor banido pelo regime, em frases

1. Este artigo é uma adaptação do capítulo 1 de minha dissertação de mestrado (Azevedo, 2011) defendida no PPGAS Unicamp com provimentos da Capes e Fapesp.

2. Entrevista realizada em 2010. Disponível em:<http://globonews.globo.com>. Acesso em: 28/07/2010

3. Entrevista concedida a Denise Rollemberg, no Rio de Janeiro, em 9 de novembro de 1996. Arquivo Edgar Leuenroth (AEL), Fundo Militância Política e Luta Armada no Brasil, Coleção Denise Rollemberg. 
como "nós estávamos fora do sistema jurídico" ou "a ditadura nos bania".

Uma semelhança, apesar da clara diferença entre as duas interpretações sobre a temática do banimento, está na disputa em torno das categorias mobilizadas e no reconhecimento - por parte dos dois narradores - da existência de um conflito que os separa. Um conflito que remete ao passado (embora lateje no presente), quando se instalou na arena política brasileira uma oposição radical que só se dissolveria pela exclusão de uma das posições antagônicas. Atualmente, múltiplas narrativas sobre esse passado, construídas ao longo do processo social, participam, ora divergindo, ora convergindo, da consolidação de símbolos e narrativas dominantes sobre nação e sociedade no Brasil. Se aquele conflito é hoje atualizado em disputas permanentes pela memória social, podemos vê-lo expressar-se, por exemplo, nos desacordos sobre as categorias mais apropriadas à abordagem do tema (se exilado ou fugitivo, por exemplo).

Devo, portanto, alertar de partida que retomarei aqui as narrativas de ex-exilados brasileiros, produzidas em entrevistas sobre suas histórias de vida. Essas narrativas inserem os processos sociais vividos no Brasil nos anos 1960 e 1970 nos marcos mais gerais do convencionalmente chamado período histórico da Guerra Fria, iluminando o contexto (inter)nacional que emoldurava e fundamentava o quadro opositivo enunciado acima. Este artigo lança um olhar sobre o conflito estabelecido naquele contexto entre "esquerda" e "direita", discutindo como esta cisão política se construía vinculando dimensões, ou campos sociais, nacional e transnacional. A partir dessa reflexão, procura entender através de quais categorias essas dimensões eram articuladas; como essas categorias, principalmente a de "inimigo", participavam da conformação de relações de violência entre as partes, e como elas representavam posições de vulnerabilidade ocupadas pelos opositores da ditadura na sociedade brasileira, dando contornos aos "eventos críticos" (Das, 1995) vividos por eles ao longo dos "anos de chumbo".

\section{Notas sobre um drama brasileiro}

\author{
Mas havia na época... não só na aviação, em todo lugar, \\ em todo lugar de trabalho, em toda nação... eu acho que \\ você não é desse período, mas havia uma... os ânimos eram \\ muito acirrados. O choque era muito evidente, havia... a \\ política aflorava muito. O país ia pra um lado ou pra outro. \\ Foi para o lado errado, mas, se fosse para o lado certo, o país \\ era outra coisa hoje. [...] Mas havia uma tendência... uma
}

tendência de se fazer uma reforma agrária que não se fez até hoje, mesmo agora. E então esse... esse... esse período tinha uma certa... os patrões tinham uma certa raiva da gente, né?[...] Bom, militamos no sindicato e a nossa militância no sindicato foi muito ativa, muito ativa! Militamos com outras direções de sindicatos de outros... outros ramos de trabalho, como os ferroviários aqui no Rio. ${ }^{4}$

No sentido que aponta a assertiva de Igor, aviador aposentado, vice-presidente de seu sindicato em 1964, "o choque" surge nas narrativas como um dos elementos mais característicos do momento então vivido pelo Brasil. Um processo conflituoso de fato alcançara nos anos 1960 grandes dimensões sociais, pois, apesar de não ter levado à ação parcelas expressivas da sociedade brasileira, transpassou-a, cindindo posições. Eventos sempre lembrados como o Comício da Central, a defesa das "reformas de base" e as Marchas da Família com Deus e pela Liberdade dão a dimensão da inserção do conflito naquela sociedade já no contexto imediatamente anterior ao Golpe de 1964. Ele ganhou força como um embate entre duas posições políticas mais gerais e antagônicas na arena, capazes de relativizar todas as outras diferenças.

Ainda durante o governo Jango, a aliança em torno das "reformas de base" desejava a democratização das instituições políticas e a modificação das bases econômicas do país. Havia variações entre as propostas e visões políticas dos grupos que as defendiam, bem como diferenças na interpretação do seu caráter, isto é, se seriam mais ou menos transformadoras, se deveriam ser implementadas por negociação ou por pressão. Contudo, as organizações políticas e os movimentos sociais ganharam projeção, unificando suas ações para tentar concretizar a ideia principal de "transformação" do Brasil, vislumbrando, em linhas gerais, justiça social e distribuição de renda. Antigas e novas organizações políticas assumiam uma postura de defesa das reformas e a necessidade da radicalização de ações e enfrentamentos para sua conquista, que deveria sair "na lei ou na marra"(Ridenti \& Reis Filho, 2002). Esses movimentos sociais e organizações políticas eram considerados - e se consideravam - "de esquerda". Como o que se esboçava era um quadro de conflito, é possível dizer com Igor que havia "outro lado". Opondo-se às reformas e ao governo Jango, posicionava-se a "direita", categoria também em geral denominada por terceiros e assumida pelos próprios. Apesar de plural em termos de propósitos e ideias políticas, esses setores da "direita" se uniam no temor às reformas e às transformações que acreditavam ver no horizonte. A postura ofensiva de seus setores mais radicais já não era uma novidade na história recente do país (Ferreira, 2004). 
Se podemos assim interpretar os termos propostos por Igor, naquele contexto, a política passou a ter centralidade na vida social brasileira, enquanto o confronto tornou-se uma estratégia privilegiada de seu exercício, vocabulário e imaginário. A associação coletiva ganhava força como meio socialmente reconhecido para garantir direitos, conformando-se na construção de grupos de opinião, pressão ou de ação, fossem eles partidos, movimentos sociais ou frentes políticas, com a intenção de manter, reformar ou revolucionar a ordem constituída. Perpetraram-se nos anos 60 processos de disputa pelo poder, que entravam com força na ordem no dia, um processo que se manteve vigoroso até a radicalização da repressão por parte da ditadura a partir do final de 1968 (Reis Filho, 2004).

Devo assinalar que não insinuo a inexistência (ou a percepção de inexistência por parte dos entrevistados) de diferenças no interior do que estou chamando de opostos nessa contenda ou, que existindo, elas não sejam importantes. Ao empregar as categorias nativas "direita" e "esquerda", mantenho em mente que cada uma congregava uma variedade interna de opiniões e práticas políticas de sujeitos e grupos, que se representavam a partir delas. Porém, com elas quero chamar a atenção para o fato de que dois paradigmas ${ }^{5}$ políticos eram definidos e fortalecidos como tais pelo conflito, erigidos em oposição primordial, polarizados primeiramente na disputa pelas reformas no governo Jango e depois no apoio/oposição à ditadura. Isso também não significa dizer que não havia posições intermediárias na sociedade; elas existiam, mas foi o conflito entre os paradigmas que passou a dar o tom às práticas e aos símbolos na arena política. É de fundamental importância notar que o conflito em questão não estava encerrado em nossas fronteiras nacionais, mas sim assumia dimensões transnacionais em um contexto em que a política era assim percebi$\mathrm{da}$, conformando os paradigmas de esquerda e direita como dois conjuntos de referenciais simbólicos e dois campos de pertencimento e de relações sociais cosmopolitas. Retomarei essa questão ao longo do texto.

No Brasil, essa relação de confronto aberto e irremediável veio a conhecer finalmente um rompimento público evidente pela ação golpista. Entendendo o processo segundo a perspectiva do conflito, convocarei o conceito de "drama social" (Turner, 2008) para caracterizar o processo de ruptura iniciado pelo golpe. Ele altera as instituições políticas e redimensiona as relações sociais, pois marca o domínio exclusivo dessas instituições por "um dos lados", iniciando uma crise pública e desencadeando um processo de ruptura simbólica entre as partes. A ditadura, de posse do poder político e com apoio de setores da sociedade, tentaria contê-la através de medidas que visavam excluir a "esquerda" da arena política. Essa exclusão encontrou entre seus principais mecanismos, formais e informais, medidas como a perseguição, a prisão, a cassação de mandato, a tortura, o desaparecimento, o assassinato, o exílio e o banimento. A violência passará a dominar o imaginário político, emergindo de ambos "os lados" na disputa pelos mesmos espaços territoriais, políticos e simbólicos. As categorias relacionadas ao exercício dessa violência, notadamente a de "inimigo", fariam uma articulação entre as mencionadas dimensões nacional e transnacional do conflito.

\section{Nação, inimigo e violência no imaginário do conflito}

Além do controle das instituições e espaços de poder político e econômico do Estado brasileiro, estavam (e permanecem) em jogo as representações e símbolos mobilizados por narrativas a respeito da "nação" e do "povo brasileiro". Parto da definição de nação como uma "comunidade política imaginada" (Anderson, 2008), para entender como os paradigmas políticos em conflito disputaram a formação desse imaginário de nação nos anos 60. Segundo Balibar (1988), produzir uma nação é, antes de tudo, produzir um povo, que é a comunidade que imagina em conjunto um Estado como seu em relação aos outros, inscrevendo seus propósitos políticos em horizontes nacionais. "Por exemplo, formulando suas aspirações de reforma e revolução social como projetos de transformação de 'seu Estado' nacional” (Balibar, 1988, p. 145). Esse povo não é uma entidade dada e homogênea, mas sim produzida em processos históricos permanentes e cheios de clivagens, em que diversos atores concorrem conflituosamente para "produzir o efeito de unidade mediante o qual o povo aparecerá aos olhos de todos como 'um povo', quer dizer, como a base e a origem do poder político" (Balibar, 1988, p. 146).

Conforme alerta o autor, esse "nós" nacional se institui encerrando diferenças internas, sendo capaz de subordinar e relativizar, fazendo primar como diferença simbólica irredutível a oposição nós $x$ estrangeiros. No caso do drama social brasileiro, o fato de os dois lados em conflito reconhecerem o Brasil como

5. Refiro-me a paradigmas, com Turner (2008), como o conjunto de símbolos e regras gerais que inspiram determinadas ações sociais e excluem outras do universo do ator, estabelecendo um regime de moralidade e de valores e apontando para o plano existencial. Apesar de o paradigma fundar reconhecimento social e pertencimento de atores a campos de relações sociais, com esse termo não me refiro a regimes ou a organizações políticas e suas práticas. 
o "seu estado", onde estavam contidas e para onde eram direcionadas suas aspirações políticas, não trazia como consequência a submissão de suas diferenças de paradigmas políticos à noção de comunidade nacional. A nação tornou-se não apenas o palco, mas o objeto da disputa em um processo em que, contudo, a oposição direita $x$ esquerda era um embate de caráter transnacional, mas que deixava de ocupar um patamar simbólico inferior e submisso à oposição nós $x$ estrangeiros. Parece notável nesse aspecto que os antagonistas tenham igualmente passado a associar em seu discurso a oposição nós $x$ estrangeiros à oposição direita $x$ esquerda, fazendo com que nas narrativas sobre o conflito, enquanto cada um dos lados estivesse sempre a favor dos interesses nacionais, o antagonista estivesse constantemente associado a interesses exógenos. Nesse contexto, deu-se um processo em que as compreensões da soberania e dos limites simbólicos do que se entendia como nação eram ressignificados por clivagens políticas, travando uma batalha pelo imaginário nacional, do qual se pretendia excluir o opositor e a legitimidade de suas posições políticas, classificando-o como "inimigo", termo associado a "estrangeiro", como veremos adiante.

No caso das narrativas elaboradas pelos entrevistados, a vinculação de categorias relacionadas a nação e paradigma se expressam de inúmeras maneiras. Ao se representarem como (ex-)"militantes de esquerda", relataram como, independentemente das dissonâncias internas, alimentavam leituras e narrativas reconhecidas como semelhantes a respeito do Brasil. Entrementes, eram inspirados na maneira de pensá-las por correntes variadas do campo político e social que denominavam "esquerda internacional" e pela dinâmica dos diferentes confrontos violentos (guerrilhas, revoluções e independências) que, desde o final de 1950, tornavam a Guerra Fria verdadeiramente quente no âmbito do então chamado Terceiro Mundo (Reis Filho, 2004). Conforme Diogo assinala a seguir, as posições políticas eram compartilhadas pela "esquerda" porque não eram definidas nos conflitos cotidianos dos grupos políticos que a compunham em suas questões setoriais, mas sim na elaboração de "projetos" estreitamente relacionados aos contextos nacional e transnacional:

A partir de 65 começou a discussão do projeto, porque nós fazíamos política estudantil, nós... é... o nosso papel, a nossa cabeça, era o seguinte: nós éramos candidatos a militantes revolucionários, fazíamos política estudantil porque éramos militantes e estávamos ali. Mas a nossa ambição era muito... ia muito além das fronteiras do movimento estudantil. ${ }^{6}$
Nesse projeto revolucionário, e também de nação, surgia "um território de fronteiras indefinidas entre a razão e a loucura, sonhos, arrogâncias, silhuetas imprecisas, generosidade sem limites, aquilo que se convencionou chamar de utopias no sentido de tudo aquilo o que transcende o imediato, o familiar, o visível a olho nu" (Reis Filho \& Moraes, 1998, p. 9). Esse território, no dizer de Turner (2008) dos "paradigmas radicais", pressupunha a transformação da ordem, geralmente traduzida pela categoria "revolução", ainda que essa categoria também pudesse ter distintos significados. A disputa entre as diferentes organizações políticas e militantes da "esquerda brasileira" por estabelecê-los, inspirados sempre por diferentes processos internacionais, com o qual compartilhavam símbolos políticos, antes de invalidar, era o que constituía seu pertencimento social a esse campo (a esquerda) transnacional, conforme pode ser observado na reflexão de Bruno:

Eu sou dessa geração que tinha vinte anos em 68, portanto estava na universidade aqui no Rio de Janeiro e participava do movimento estudantil, que nessa altura, em 68, já era bastante forte. Inclusive eram movimentos, sobretudo o movimento estudantil, né? Era um movimento de contestação à ditadura muito forte nesse período. É o ano que vem o AI-5, então a juventude, pelo menos uma boa parte da juventude, é consciente, né? Ela se organiza, ela vai às ruas, entra nos partidos políticos, quer nos existentes, quer criando outros. No início da década de 60 havia aí a revolução cultural acontecendo na China, havia Cuba, né? Che Guevara tinha acabado de morrer na Bolívia, mas tinha deixado a sua bandeira, então Cuba tava ali do lado dos Estados Unidos, já um país socialista. Havia todo um movimento progressista no período da Guerra Fria e, digamos, o lado socialista dessa Guerra Fria era o lado que estava em ascensão. ${ }^{7}$

O paradigma de esquerda marcava ainda um compromisso com a "ação" ou a "prática", fazendo-os nutrir uma ética da luta ((Reis Filho \& Moraes, 1998), que, como nos apontam Carla e Nelson, também significava compartilhar uma forma de concatenar uma leitura de sua própria vivência. Uma leitura que dava primazia às experiências políticas e trazia para a vida pessoal não apenas a perspectiva da ação e da transformação do país, mas dos antigos valores, trazendo a "revolução" para a própria vida:

Então, isso foi o clima em que eu vivi a universidade. Teve uma época em que eu era presidente do diretório, que eu tinha três assembleias por semana pelo 
menos e um programa no rádio. Eu ia para o meio rural em caminhão com os seminaristas e a gente fazia teatro popular, CPC da UNE, aquelas coisas todas para os agricultores. Tinha uma reunião de sindicato operário, tinha uma assembleia na faculdade e um programa de rádio e naquela época a gente pensava que ia fazer a revolução, então era a maior mandação de brasa. Aí em 64, quando eu me formei, eu fui convidada pra ser coordenadora nacional de JUC e o meu pai... Eu fui criada, enfim, pra ser mãe de família... enfim, não pra sair de casa aos 22 anos pra ir para o Rio de Janeiro sozinha, não era a perspectiva da minha família. O meu pai já não sabia mais o que fazer comigo, quando eu disse pra ele: “Ó, fui convidada pra ir para o Rio de Janeiro pra coordenação de JUC". Ele disse: "Pode ir, minha filha". 8

Meu pai no Paraná foi vereador pela UDN e a família tanto da minha mãe quanto do meu pai eram fazendeiros de café e estavam ligados à política. Eu descobri agora há pouco.... Você vê, vai escavar! Que meu avô, meu avô materno, era o chefe do integralismo lá na minha região, que eu não sabia. Sabia que eram conservadores, reacionários, racistas, mas nunca soube o quanto. [...] Aí você tem um pouco da história que você, quando jovem, se rebela contra a tradição familiar. Então a minha rebeldia com opção... sem opção um pouco, parte de um contexto que você vai contra. E eu fui contra, o mais imediato era a ditadura, tinha a ditadura a gente se rebelava enquanto estudante, mas junto tinha o problema da família. A minha família apoiava aquilo, a minha família foi daquelas que apoiou a ditadura em 64, a Marcha da Família com Deus pela Liberdade... me levaram! E eu fui, porque ainda tava dentro disso, né??

Comentando a expressão dessa utopia revolucionária nas manifestações artísticas da época, Ridenti (2000, p. 44) lança palavras que, a meu ver, valem para compreendermos o "paradigma de esquerda" de maneira mais geral e seu caráter (trans)nacional:

Nos anos 60, a utopia que ganhava corações e mentes era a revolução (e não a democracia ou a cidadania, como seria anos depois), tanto que o próprio movi- mento de 64 designou-se como revolução. As propostas de revolução política, e também econômica, cultural, pessoal, enfim, em todos os sentidos e com os significados mais variados, marcaram profundamente o debate político [...] enquanto uns inspiravam-se na revolução cubana ou na chinesa, outros mantinham-se fiéis ao modelo soviético, enquanto terceiros faziam a antropofagia do maio francês, do movimento hippie, da contracultura, propondo uma transformação que passaria pela revolução dos costumes. Rebeldia contra a ordem e revolução social por uma nova ordem mantinham diálogo tenso e criativo, interpenetrando-se em diferentes medidas na prática dos movimentos sociais.

Chamemos de utopias ou paradigmas, eles encontravam inspiração nos processos sociais que transcendiam fronteiras nacionais, compartilhando referenciais simbólicos com atores em outros espaços e arenas, uma vez que a dinâmica social da Guerra Fria tornara a política um campo internacional, levando a oposição esquerda $x$ direita a antagonismo de um conflito que assumia escala mundial. Entrementes, as arenas onde esse conflito se estabelecia e era simbolizado, muitas vezes, eram os Estados Nacionais, constituindo o imaginário de nação como um dos símbolos mais disputados. É, portanto, nesse sentido que o reconhecimento das dimensões simbólicas envolvidas nos embates políticos se fazia presente e integrava as narrativas mobilizadas pelos defensores de paradigmas em forma de acusações mutuamente lançadas. Daí que "esquerda" e "direita" se considerassem inseridas em uma luta feita não em nome de si, mas do "povo brasileiro" que deveria ser protegido de seus "inimigos", associados a estrangeiros e seus interesses. Vejamos.

A "direita", focada no aspecto da soberania, acusava os envolvidos com a "esquerda" de ameaçála, aliando-se a forças exógenas (soviéticos, chineses ou cubanos, por exemplo), constituindo uma "ameaça aos interesses e à segurança nacional”. ${ }^{10}$ Chamandoos de "subversivos", "terroristas" ou "inimigos da pátria”, excluía-os retoricamente e na prática do conjunto do "povo brasileiro".11 A esquerda, por sua vez, considerava "povo" somente aqueles setores da

\section{Entrevista com Carla realizada em Porto Alegre, em 1 de fevereiro de 2010.}

9. Entrevista com Nelson realizada em São Paulo, em 12 de março de 2010.

10. É interessante nesse sentido que a Lei de Segurança Nacional (LSN - Decreto-lei $n^{\circ} 314$, de 13 de março de 1967), ao tipificar os crimes contra a segurança nacional, cite a palavra "estrangeiro" em quase todos os seus artigos. O Art. $3^{\circ}$, § 3 diz: "a guerra revolucionária é um conflito interno, geralmente inspirado em uma ideologia ou auxiliado do exterior, que visa à conquista subversiva do poder, pelo controle progressivo da nação".

11. Representações sobre "militantes de esquerda" como desviantes sociais, cujo apartamento máximo é justamente considerá-los não brasileiros, estrangeiros ou inimigos da nação, não são novidades criadas na ditadura, mas estão inseridas em uma verdadeira tradição anticomunista brasileira que remonta ao surgimento das primeiras experiências de "socialismo real". O "comunista" subversor da ordem social, da cultura e da família brasileira, fiel a pensamentos estrangeiros, tornou-se desde então suspeito preferencial dos órgãos policiais (Pereira, 2004), mas também de inúmeros outros setores da sociedade brasileira (Motta, 2002) 
sociedade que via como beneficiários de suas propostas de transformação (trabalhadores, camponeses, estudantes), excluindo quem considerava, tomando as eloquentes palavras de Brizola (apud Ferreira, 2004, p. 198): "uma minoria de brasileiros vendilhões de sua pátria, minoria poderosa e dominante sobre a vida nacional". Estes eram o "antipovo", os "gorilas", que também estariam relacionados diretamente aos interesses "imperialistas" dos Estados Unidos. De sorte que as narrativas sobre a ameaça externa à nação, com que o antagonista compactuava e da qual deveria ser defendida, forjavam o "inimigo" como sua categoria central, estreitamente relacionada à escala de violência que se seguiria ao golpe, quando ambas as partes passaram a considerar a existência de uma "guerra" em curso.

A perspectiva de um enfrentamento mais violento com o regime ganhará força na defesa da ideia de "guerra revolucionária". Ainda que nem toda "esquerda" tenha optado pela luta armada, a combinação de dois processos mais importantes tornou-a seu principal meio de atuação. O entendimento da "estratégia revolucionária" como um processo de insurgência violento, inspirado no cubano ou chinês, por exemplo, tornou-se não apenas majoritário na "esquerda brasileira", como também urgente, passando a ser visto por diversos agentes como a melhor - quiçá a única - forma de combater a ditadura. ${ }^{12} \mathrm{Em}$ contrapartida, os movimentos sociais haviam esmorecido após duas importantes vagas de repressão do regime. A primeira, aberta pelo Golpe, atingiu principalmente o movimento sindical e os partidos a ele vinculados, estendendo-se até 1966. Nos anos imediatamente seguintes, houve certa tolerância, principalmente em relação à classe média, notadamente ao movimento estudantil, que seguiu atuando apesar dos percalços. Esse quadro mudou após a retomada das mobilizações e o crescimento da luta armada, atravessados pelo fechamento definitivo do regime, de que o AI-5 é o marco simbólico. Nesse novo contexto, alguns militantes vindos de movimentos sociais anteriores passaram à luta armada, outros já iniciavam sua atuação política diretamente nela, que seguia, embora socialmente isolada, militando sob a repressão:

A ideia da luta armada começava, claro, amadurecer. A esquerda pré-64 responsabilizada pelo fracasso dos grandes movimentos sociais anteriores ao golpe, todo seu projeto moderado de transição pacífica através das reformas era varrido e em seu lugar aparecia a perspectiva da luta armada e era isso que nos empolgava: como fazer a luta armada? Foco guerrilheiro? Guerrilha urbana? ${ }^{13}$

E aí, já 66, eu comecei realmente a me aproximar de uma forma mais efetiva da Polop, só que aí a Polop... começou todo um processo de divisão da esquerda brasileira, a Polop foi uma delas que dividiu também. Ficamos como um núcleo em Minas Gerais, um núcleo forte de movimento de esquerda, tinha muita influência no movimento estudantil. Quando eu entrei pra faculdade, eu já militava na organização, militava no aparelho da organização mesmo, tanto que eu nunca fiz movimento estudantil, nunca participei de uma passeata, nunca participei de nada disso. ${ }^{14}$

A ditadura, por sua vez, assumiria com todo o aparato estatal seu lugar na batalha, consolidando um sistema nacional de segurança e informação, baseado também na "guerra revolucionária ou interna" e no “crime de subversão", tipificado pela Lei de Segurança Nacional, a base jurídica e simbólica para identificar e combater o "inimigo interno" (Fico, 2001). Vale salientar que o posicionamento desigual nas estruturas de poder colocava sua violência em patamares absolutamente superiores à da luta armada. Constituindo-se como política de Estado, o terror era institucionalizado como meio de dissuasão do conflito. A estrutura repressiva contava com dois sistemas: o de informação, formado por uma rede de órgãos civis e militares de espionagem, responsável por identificar, produzir informações e, sobretudo, um discurso sobre a periculosidade do "inimigo", visando marginalizá-lo. O produto desse trabalho servia principalmente à atuação do sistema de segurança, rede policial e militar de repressão, responsável por aplicar as medidas de "ação corretiva" (Fico, 2001). A atuação dos dois sistemas era independente, mas relacionada: se uma profusão de leis regulamentava o funcionamento do sistema de informação, tipificando crimes e o processo penal nos tribunais militares, ela não excluía o caráter de exceção no qual operava o sistema de segurança. Essa duplicidade torna difícil ainda hoje traduzir em número todos os que foram, em alguma medida, atin-

\footnotetext{
12. O PCB era o principal partido de esquerda até a ditadura, mas, apesar de contrário à luta armada às vésperas do golpe, este não é o marco inicial das ações ou intenções violentas de outros grupos. Contudo, o novo momento fortalece essa opção para boa parte dos militantes organizados. A luta armada se tornará então uma das principais razões de desavenças e "rachas" não só no PCB, mas nas principais organizações de esquerda da época, como a POLOP e a AP, dando lugar a vários grupos guerrilheiros. Essas novas organizações possuíam grande expectativa no próprio papel mobilizador e na utopia revolucionária e encontravam apoio, principalmente treinamento, junto a países e organizações que se integravam à esquerda internacional. Sobre a importância destacada de Cuba, ver Rollemberg (2001).
}

13. Entrevista concedida a Denise Rollemberg. Rio de Janeiro, 9 de novembro de 1996

14 Entrevista com Rodrigo realizada em Brasília, em 31 de maio de 2010. 
gidos, pois, conformada como política de estado, o uso da violência adquiriu um aspecto exemplar sobre a sociedade, observando, conforme Taussig (1993, p. 30), "a necessidade de controlar populações numerosas, classes sociais inteiras e até mesmo nações, através da elaboração cultural do medo". Vejamos como isso se dava.

Associados tanto a "estrangeiros comunistas" e seus interesses de domínio sobre o Brasil, quanto a "marginais" comuns, a "bandidos" que assaltavam bancos e punham famílias em risco - conforme sustentavam os cartazes que estampavam, por todo Brasil, os rostos dos "terroristas procurados" -, a violência da ditadura pretendia isolá-los do mundo social e, ironicamente, esvaziar o conteúdo político de suas ações e, sobretudo, de suas vidas. ${ }^{15}$ Nessa condição, a tortura, quiçá a morte ou a obscura figura do desaparecimento, produtos extremos do arbítrio, constituíam o universo de possibilidades inscritas em seus horizontes. Firmando-se como certezas incertas, elas impuseram novas dinâmicas para os que continuariam atuando politicamente de modo a garantir a sobrevivência, mas que significavam um apartamento social, que podia vir ora como exílio, ora como clandestinidade. Ambas as experiências constituíam, sob esse aspecto, formas de "liminaridade", marcando para os dissidentes o início de um processo de transição entre diferentes estados estruturais, quando, como inimigos, deixaram de ocupar qualquer "condição estável ou recorrente culturalmente conhecida" (Turner, 2005, p. 137). Segregados, tornavam-se "estruturalmente, ou mesmo fisicamente, invisíveis" para o conjunto da sociedade (Turner, 2005, p. 139). Muitos depoimentos referem-se à instabilidade dessa condição, como no relato de Selma, que, apesar das ações clandestinas na ALN, vivia legalmente em São Paulo, sem ter sido descoberta pela repressão, quando foi presa:

Presa porque? Porque tava com uma dirigente $[\ldots]$ no carro [...] Ela era dirigente, mas eu era... eu tava junto. Bom, daí fomos pra Oban, todo aquele processo Oban, Dops, presídio Tiradentes etc. Fui medianamente torturada, né? Não das mais torturadas, mas bastante torturada [...]. Bom, como eu neguei tudo o tempo inteiro, eu sei que eu saio, acho que em agosto de 70, em liberdade condicional, mas daí eu voltei... vim morar com meus pais de novo. Toda segunda-feira eu ia lá assinar o negócio... a presença na auditoria militar e já voltei a militar. Daí, a gente tava preparando uma missão, uma coisa assim, e o pessoal foi preso depois desse troço feito. E uma das pessoas, que foi presa, pelas fotos me denunciou. [...] então eu fui denunciada por este companheiro, que ele tava na tortura na Oban e eu tava solta e ia na auditoria na segunda-feira. Sorte que alguém do presídio tava lá na Oban, ouviu isso, conseguiu avisar o advogado, que conseguiu me avisar. E eu na segunda-feira não fui assinar, chispei. Entrei pra clandestinidade imediatamente maquele dia. ${ }^{16}$

A violência desses eventos marcaria suas trajetórias e o processo de reconstrução de suas memórias como experiências coletivas, fazendo do engajamento político e das incertezas postas pelo terror, ora juntos, ora separados, elementos importantes de suas narrativas. É o caso da fala de Marcos, que já tinha passado por uma experiência de prisão pelo exército e, mesmo após deixar a militância, continuava sendo perseguido pelo Dops. Sem interesse em ingressar na luta armada e sem condições de viver sem apoio na clandestinidade, decide sair do país:

No Rio eu andava meio semiclandestino, porque a situação já tava tensa, mudava muito de casa... Quer dizer, o único lugar fixo era realmente o trabalho. Mas eles deram [durante sua prisão] mais atenção à minha militância no Rio mesmo, na Ames e na Fuec, no movimento estudantil do Rio [...] isso foi naquela altura do AI-5. Então muito bem, o que acontece é que, quando eu fui solto, ainda não existia a articulação dos órgãos de repressão, o DOI-Codi ainda não... com certeza o que me procurava no Rio era Dops do Rio e o que aconteceu foi o seguinte: o exército me soltou, não me entregou pro Dops. Porque depois do DOI-Codi, você saía de um, eles te entregavam pra outro. Não foi o que aconteceu comigo, o que aconteceu foi que, quando... eu fui solto, voltei a trabalhar. Como o movimento estudantil naquela situação pós-AI-5.... quer dizer uma parte dos meus amigos foram para luta armada, outros, pra usar o termo da época, desbundaram... Então, quando eu fui solto, eu voltei só pra Contag. Um dia eu chego em casa e o porteiro me avisou: "Dops teve aí atrás de você". Por acaso foi um dia que eu não fui dormir em casa [...]. E nessa altura, como eu tava prevendo mais ou menos o que ia acontecer, eu tirei o passaporte... ${ }^{17}$

Nessa dinâmica de ação e repressão, uma constante produção e circulação de boatos, histórias e de-

\footnotetext{
15. Refiro-me à noção talvez historicamente estabelecida na sociedade brasileira de que o indivíduo socialmente categorizado como "bandido" não é uma pessoa digna de direito, é uma vida desprovida de valor político, um homo sacer (Agamben, 2007) - definição na qual também parece se enquadrar o "inimigo" que, note, distingue-se de um "adversário", justamente pelo esvaziamento de seus direitos políticos.
}

16. Entrevista com Selma realizada em Brasília, em 31 de maio de 2010.

17. Entrevista com Marcos realizada em Campinas, em 27 de fevereiro de 2010. 
núncias sobre o arbítrio, fiéis aos fatos ou hiperbólicas, povoavam o imaginário da esquerda, tornando o terror uma categoria presente na realização de toda atividade política, conforme mencionado, algo que teve grande impacto sobre os movimentos sociais. A certeza incerta da prisão foi a razão pela qual Raquel e Nelson decidiram deixar o país:

O clima também era muito... tem uma coisa que até hoje eu acho que é meio negligenciado, o pessoal fala sempre que foi preso e que foi torturado, ou a organização... mas havia também um clima de medo tão grande que você.... tinha medo! Você tinha medo de quase tudo! Então nesse clima de medo, alguns de nós tomamos essa iniciativa. Eu ainda com o passaporte na mão, pude optar ainda com passaporte, depois perdemos, né? Antes que eu caia. Eu não aguento! Era uma coisa de não aguentar aquele clima, o clima era... não é só de terror, de iminência de prisão, o clima era de medo, você tinha medo de quase tudo, com o clima de medo que se criou, você pensava e não via perspectivas. Deixa eu saltar fora antes que me peguem ou antes que eu fique louco. ${ }^{18}$

Eu era da AP, JUC, esses movimentos de base e depois, quando já estava na universidade... depois eu fiz vestibular na USP, entrei na psicologia e daí eu estava muito próxima de umas pessoas da ALN. Embora não fosse uma militante da ALN, eu era próxima deles. Fiquei dois anos na USP, aí alguns amigos meus começaram a ser presos. Eu resolvi ir para o Chile. ${ }^{19}$

No entanto, a profusão dos discursos sobre o perigo subversivo e a necessidade de combate ao inimigo na sociedade brasileira fazia repercutir esse universo de medo também entre os defensores da ditadura, e, mesmo entre os politicamente indiferentes ao conflito, o que justificava tanto a ação repressiva quanto a omissão de quem a tolerava ou defendia. Nesse sentido, o medo dos "terroristas" era mais que uma peça de propaganda, a supervalorização discursiva de suas capacidades de atuação pelo regime refletia um temor real, ainda que pudesse ser exacerbado no jogo da disputa política. Esse temor era reelaborado e realimentado em diferentes arenas da prática social em que se davam enfrentamentos e produção de narrativas. Os entrevistados revelam como esses discursos se embatiam até mesmo no interior de suas famílias, onde o medo do comunismo se tornava "ambiguidade" quando o comunista era o próprio filho:
Meu pai era um empresário. Um homem muito bom, mas envolvido pela elite local e ele foi inclusive vereador da Arena e na época os militares chamavam os empresários para envolvê-los e comprometê-los, diziam que o comunismo vinha que... tal. Meu pai foi chamado também pra estas coisas, mas a minha casa em Ijuí era o local onde se hospedava todo mundo do movimento estudantil, então meu pai vivia uma ambiguidade, né? De, por um lado, dar proteção aos filhos e amigos dos filhos que faziam trabalho político e, por outro lado, ser empresário, ser envolvido e o exército chamar, essas coisas, que era muito típico da época, né? Tinha uma garagem na minha casa que o pessoal da União Gaúcha dos Estudantes Secundaristas (Uges) [...] faziam reunião [...] e dormiam, inclusive. [...] Eles colocaram um cartaz: "Subsede da Uges" [...], e a vizinhança dizia para o meu pai: “Tu tá abrigando comunista!"20

Eles sabiam que eu tinha ligação política na universidade, não sabiam o quanto, mas sabiam que tinha problema, né? Meus pais não acreditavam que havia tortura. Eu dizia pra eles... era o clima da época, eu falava pra eles: "Olha, mais um foi preso e torturado!". Eles achavam que era invenção dos comunistas, era propaganda contra o governo que eles defendiam, né? A ditadura militar. Era propaganda contra. ${ }^{21}$

As narrativas encontravam lugar em um espaço aberto entre o universo dos acontecimentos, das possibilidades e de suas representações. O conflito forjava para toda sociedade "uma realidade incerta, a partir da ficção, dando contornos e voz à forma informe da realidade, na qual uma atuação recíproca da verdade e da ilusão torna-se uma força social fantasmagórica" (Taussig, 1993, p. 126). Contudo, a ruptura simbólica que engendrava essas narrativas sobre o inimigo, parece-me, não constituía um rompimento efetivo das relações entre as partes, antes inaugurava relações de "exceção" (Agamben, 2007), mesmo no caso extremo de saída/expulsão desses "inimigos" do território brasileiro, se aceitarmos que "a existência do outro é desde o início posta no ato que o exclui" (Clastres, 2004, p. 251). O exílio torna mais explícita a relação entre violência, nação e paradigmas transnacionais na conformação dos "anos de chumbo" brasileiros, além de salientar sua participação no contexto político internacional firmado pela Guerra Fria.

18. Entrevista com realizada Nelson em São Paulo, em 12 de março de 2010

19. Entrevista com Raquel realizada em Goiânia, em 2 de junho de 2010

20. Entrevista com Carla realizada em Porto Alegre, em 1 de fevereiro de 2010.

21. Entrevista com Nelson realizada em São Paulo, em 12 de março de 2010. 


\section{Ame-o ou deixe-o}

Através de uma autorrepresentação por meio da categoria "militante de esquerda", os entrevistados nos falam de atores políticos inseridos em um campo de relações que extravasam fronteiras. Falando de suas trajetórias, por vezes apresentam a dificuldade de delimitar momentos, como o exílio, o banimento e a militância clandestina, evidenciando a continuidade existente entre eventos, cuja passagem de um a outro era frequentemente tênue e mais associada ao pertencimento à esquerda internacional e à ação repressiva do governo brasileiro do que ao cruzamento de fronteiras. Observemos a trajetória de Wagner:

Eu fui preso anos depois no Uruguai, deportado pro Brasil e saí no... Fui trocado no sequestro que o Lamarca, o capitão Carlos Lamarca, fez em 1970... Fins de 70 e eu saí em janeiro, 14 de janeiro de 1971. Fui banido para o Chile, naquele grupo dos 70 que foram banidos para o Chile. No Chile eu fiquei asilado lá até o golpe que derrubou o Allende e um mês depois me asilei na embaixada do México e fui para o México. Mas no México, o governo mexicano não deixou a gente ficar lá, porque ele só queria que só ficassem chilenos e ele expulsou os brasileiros, uruguaios, bolivianos etc... Então, mais uma vez, pus o pé na estrada e fui parar na Suécia.

Resumidamente, poderiamos dizer que Wagner, como tantos outros militantes brasileiros, realizava clandestinamente atividade política no Uruguai, quando foi preso e enviado ao Brasil. Naquele país, muitos exilados brasileiros viveram, sempre mantendo contatos e trânsitos com militantes e organizações entre os dois (e também outros) países do Cone Sul. Do presídio, Wagner só pôde sair "trocado" no sequestro do embaixador suíço em 1971, o que lhe rendeu banimento. Uma vez no Chile, tornou-se novamente um militante clandestino, tentando articular um treinamento de guerrilha na Guiné Bissau e voltar ao Brasil. O golpe de Pinochet, contudo, o surpreende, tornando-o um exilado, refugiado em uma embaixada europeia. Sua trajetória expressa tanto a liminaridade impressa nessas diferentes categorias ("exilado", "banido" ou "militante na clandestinidade") quanto revela, em sua circulação internacional, as articulações e fidelidades políticas desenvolvidas no interior das redes sociais conformadoras da "esquerda internacional". Contudo, se, no exemplo de Wagner, como em outros, as fronteiras territoriais não consti- tuíam limites para a atuação política dessa "esquerda", pode-se dizer o mesmo em relação à repressão brasileira que o prendeu não no Brasil, mas no Uruguai.

A noção de translocalidade proposta por Appadurai (1997) parece esclarecedora, não apenas de como fluxos de deslocamento de pessoas, ideias e objetos podem estabelecer campos sociais de relacionamento entre estados nacionais e localidades, tal como o autor propunha, mas também podemos considerá-la como um fenômeno que os próprios Estados-nações podiam promover, uma vez que suas instituições de informação, sua ação policial e suas leis muitas vezes extravasavam as fronteiras territoriais para garantir a "segurança nacional". Sabe-se que um campo de translocalidade entre as polícias políticas no Cone Sul (especialmente, mas não apenas nele) foi construído gradativamente (nesse caso até se integrar no Plano Condor), envolvendo formas de colaboração entre as ditaduras da região no combate a seus inimigos internos. Esses governos, através de seus órgãos repressivos e mesmo de suas embaixadas, não apenas trocavam experiências e treinamentos, como faziam incursões em territórios vizinhos. ${ }^{22}$ Esse foco dos estados nacionais no controle sobre pessoas, mais que sobre territórios, parece ter sido especialmente importante nesses anos de Guerra Fria, quando estavam em curso inúmeras circulações migratórias com finalidades políticas, como as de Wagner, movidas por fidelidades tanto nacionais quanto a paradigmas transnacionais, razão pela qual eram consideradas perigosas pelos estados nacionais.

Essa relação entre exceção, poder e exílio que assim se revela ganha um sentido especial no caso brasileiro, onde o regime de exceção e o exílio tiveram um início simultâneo na figura do presidente que deixou, em 1964, concomitantemente, o poder e o país. O exílio, configurando aqui a metáfora da exceção, se confunde historicamente com ela, evidenciando que o lugar da soberania é o poder, não o direito, que pode ser suspenso e reformulado. Conforme alerta Agamben (2007), o poder soberano, assim como o exílio e qualquer outra exceção, funda-se na condição de estar ao mesmo tempo dentro e fora do ordenamento legal. Interessante, entretanto, é notar que, mesmo o exílio surgindo de forma coeva ao estado de exceção, isto é, sem necessitar de um "decreto para exilar ninguém", que o general alhures reivindicava, no ano de 1969, o "bacharelismo legiferante" (Fico, 2001, p. 82) brasileiro entrou em cena, trazendo para o ordenamento a figura jurídica do banimento, que, ironicamente, inclui para excluir.

Com a excepcionalidade que lhe era própria, a ditadura impôs, segundo o ordenamento lhe permi- 
tia, o Ato Institucional $n^{\circ} 13$, por ocasião da troca dos primeiros quinze presos políticos pelo embaixador dos Estados Unidos sequestrado. ${ }^{23}$ Pretendia com o Ato explicitar o não valor político daquelas vidas, excluindo-lhes a cidadania nacional e os direitos associados a ela, entre os quais se encontram os relativos à proteção da vida e dos direitos individuais (Arendt, 1989). Da mesma maneira que outras medidas de que viemos falando, o exílio ou o banimento eram relações através das quais a ditadura consolidava o Estado-nação pela relação de exceção com a "vida nua" (Agamben, 2007) de seus inimigos. Se eles sugerem, por um lado, que o território (geográfico) é o espaço de proteção soberana do Estado, revela também que ele não é sua fronteira absoluta, pois a nação se afirma para além dele, permanecendo relacionada aos sujeitos no exílio, na medida em que os define como vida politicamente desqualificada. Esses inimigos no espaço geográfico não nacional, expulsos com ou sem lei, guardam na relação de expulsão uma afirmação de soberania e limites nacionais, revelando que a relação social com a população é território (político) do Estado-nação, ${ }^{24}$ onde atua, seja protegendo vidas políticas (dos direitos humanos de seus cidadãos nacionais), seja arbitrando sobre corpos e vidas de seus inimigos, considerados sem valor político (Agamben, 1996, 2007).

\section{Considerações finais}

Diante do exposto até aqui, parece-me possível afirmar que as narrativas políticas "de esquerda" e "de direita" de que viemos falando condensavam (e acredito ser possível dizer que em grande medida ainda o fazem) as dimensões nacional e transnacional do conflito estabelecido entre elas. As narrativas da ditadura, mobilizadas por todo um aparato de Esta- do, empurravam aqueles que, em outra situação, poderiam ser tomados como adversários políticos para a (não) posição social de "inimigos da pátria". Por certo, a relevância das simbologias do inimigo para a sedimentação violenta de comunidades nacionais e nacionalismos não é propriamente uma exclusividade brasileira ou da época mencionada. Conforme salientou Thomaz (2004), são inúmeros os casos em que determinados grupos sociais tidos como outsiders (Elias \& Scotson, 2000) são representados como estrangeiros e/ou inimigos, forjando sobre categorias étnicas ou nacionais processos de diferenciação social tanto de grupos locais quanto daqueles inseridos em redes translocais (de que os tutsis em Ruanda, no primeiro caso, os judeus em diversos países europeus ou os indianos em Moçambique, no segundo, seriam exemplos).

Contudo, parece-me possível afirmar uma particularidade do processo brasileiro no período em questão: se aqueles processos envolviam disputas pelo poder, possuindo, sob esse aspecto, um caráter político, eu diria que, no Brasil durante a Guerra Fria (e provavelmente não só aqui), as representações sobre o inimigo vinculavam categorias de nacionalidade àquelas referentes aos paradigmas políticos transnacionais. Se nesse "quente" contexto, no Brasil, como em outras partes, foi conferida à violência a condição de meio, como outrora aludiu Clastres (2004), na busca de um fim, igualmente político, esse fim parece ter sido não apenas a marginalização da "esquerda", mas a própria consolidação simbólica da nação brasileira perante o cenário mundial rasgado pelo conflito político entre "direitas e esquerdas". Diante do quadro de (inter)nacionalismos imbricados, a ditadura marcava pela estigmatização e exclusão de seus "inimigos" os limites da nação brasileira perante não simplesmente outras nações, mas ao contexto transnacional da política e da condição bipolar dos paradigmas.

\footnotetext{
23. O Al-13 criava o expediente do banimento no ordenamento jurídico brasileiro. A partir daí, decretos seguintes baniriam, um a um, pouco mais de cem presos políticos, que, ao longo de quatro ações de mesmo tipo, foram trocados por embaixadores.

24. Esta perspectiva está presente no Decreto-lei $n^{\circ} 898$, de 20 de setembro de 1969, que deu nova redação à LSN, art. $4^{\circ}$ : "este artigo se aplica sem prejuízo de convenções, tratados e regras de direito internacional aos crimes cometidos, no todo ou em parte, em território nacional ou que nele, embora parcialmente, produziram ou deviam produzir seu resultado". No art. 50: "ficam sujeitos ao presente decreto-lei, embora cometidos no estrangeiro os crimes que, mesmo parcialmente, produziram ou deviam produzir seu resultado no território nacional".
} 


\section{Referências}

AGAMBEN, Giorgio. Homo sacer: o poder soberano e a vida nua I. Tradução de Henrique Burigo. Belo Horizonte: Editora UFMG, 2007.

Política del exilio. Archipiélago: Cuardenos de Crítica de la Cultura, Barcelona, n. 26-27, p. 41-52, 1996.

ANDERSON, Benedict. Comunidades imaginadas: reflexões sobre a origem a difusão do nacionalismo. Tradução de Denise Bottman. São Paulo: Companhia das Letras, 2008.

APPADURAI, Arjun. Soberania sem territorialidade: notas para uma geografia pós-nacional. Novos Estudos Cebrap, São Paulo, n. 49, nov. 1997.

ARENDT, Hannah. Origens do totalitarismo. Tradução de Roberto Raposo. São Paulo: Companhia das Letras, 1989 BALIBAR, Étienne. La forma nación: historia y ideología. In: BALIBAR, E.; WALLERSTEIN, I. Raza, nácion y clase. Madri: Iepala, 1988.

AZEVEDO, Desirée de Lemos. Os melhores anos de nossas vidas: narrativas, trajetos e trajetórias de exilados brasileiros que se tornaram cooperantes na República popular de Moçambique. 2011. Dissertação (Mestrado em Antropologia Social) - Universidade Estadual de Campinas, 2011. CLASTRES, Pierre. Arqueologia da violência: a guerra nas sociedades primitivas. Arqueologia da violência. Tradução de Paulo Neves. São Paulo: Cosac \& Naify, 2004 DAS, Veena. Critical events: an anthropological perspective on contemporary India. New Delhi: Oxford University Press, 1995.

ELIAS, Norbert; SCOTSON, John L. Os estabelecidos e os outsiders: sociologia das relações de poder a partir de uma pequena comunidade. Rio de Janeiro: Jorge Zahar, 2000. FERREIRA, Jorge. A estratégia do confronto: a Frente de Mobilização Popular. Revista Brasileira de História, São Paulo, v. 24, n. 47, p. 181-212, 2004.

FICO, Carlos. Como eles agiam: os subterrâneos da ditadura militar- espionagem e polícia política. Rio de Janeiro: Record, 2001
MOTTA, Rodrigo Patto Sá. Em guarda contra o perigo vermelho: o anticomunismo no Brasil (1917-1964). São Paulo: Perspectiva, 2002.

PEREIRA, Luciana Lombardo Costa. Polícia política e caça aos comunistas: repressões e pressões sobre o movimento operário no Rio de Janeiro (1945-1964). In: MATTOS, Marcelo Badaró (Coord.). Trabalhadores em greve, polícia em guarda. Rio de Janeiro: Bom Texto, 2004.

QUADRAT, Samantha. Muito além das fronteiras In: REIS, Daniel Aarão; RIDENTI, Marcelo; MOTTA, Rodrigo Patto Sá (Orgs). O golpe e a ditadura militar quarenta anos depois (1964-2004). Bauru: Edusc, 2004.

REIS FILHO, Daniel Aarão; MORAES, Pedro. 1968: a paixão de uma utopia. Rio de Janeiro: FGV, 1998.

REIS FILHO, Daniel Aarão. Ditadura e sociedade: as reconstruções da memória. In: REIS, Daniel Aarão; RIDENTI, Marcelo e MOTTA, Rodrigo Patto Sá (orgs). O golpe e a ditadura militar quarenta anos depois (1964-2004). Bauru: Edusc, 2004.

RIDENTI, Marcelo. Em busca do povo brasileiro: artistas da revolução, do CPC, à era da TV. Rio de Janeiro: Record, 2000.

RIDENTI, Marcelo; REIS FILHO, Daniel Aarão (Orgs.). História do marxismo no Brasil. Volume V: Partidos e organizações dos anos 20 aos 60. Campinas: Ed. Unicamp, 2002.

ROLLEMBERG, Denise. O apoio de Cuba à luta armada no Brasil. Rio de Janeiro: Mauad, 2001.

TAUSSIG, Michael. Xamanismo, colonialismo e o homem selvagem: um estudo sobre o terror e a cura. Tradução de Carlos Eugênio Marcondes de Moura. Rio de Janeiro: Paz e Terra, 1993.

THOMAZ, Omar R. Entre inimigos e traidores: suspeitas e acusações no processo de formação nacional no Sul de Moçambique. Travessias: Revista de Ciências Sociais e Humanas em Língua Portuguesa, Lisboa, v. 4-5, p. 269-288, 2004. 
TURNER, Victor. Dramas, campos e metáforas: ação simbólica na sociedade humana. Tradução de Fabiano Morais. Niterói: Eduff, 2008

\title{
About gorillas and subversives: memories of a conflict in Brazil
}

\begin{abstract}
This article examines the interweaving of issues related to nation, politcs, exile and conflict in social processes experienced by Brazil in the 1960 and '70s, inserted in general frameworks of the so-called historical period of the Cold War. To do so, I will start with categories associated with these issues convened by the memories of brazilian political exiles in the construction of narratives about critical events experienced by them over the "lead years".
\end{abstract}

Keywords: memory; politics; nation; exile; Cold War.

\section{Acerca de los gorilas y los subversivos: recuerdos de un Brasil en conflicto}

\section{Resumen}

Este artículo examina la imbricación de cuestiones relacionadas con la nación, política, exilio y conflicto en los procesos sociales experimentados por Brasil en la década de 1960 y 70, incluidos en marcos más generales del período histórico nombrado de Guerra Fría. Para ello, voy a utilizar las categorías asociadas a estos temas convocadas por las memorias de los ex-exiliados políticos brasileños en la construcción de narraciones de eventos críticos experimentados por ellos en los "años de plomo".

Palabras clave: memoria; política; nación; exilio; Guerra Fría.

Data de recebimento do artigo: 25/04/2011

Data de aprovação do artigo: 29/07/2011 